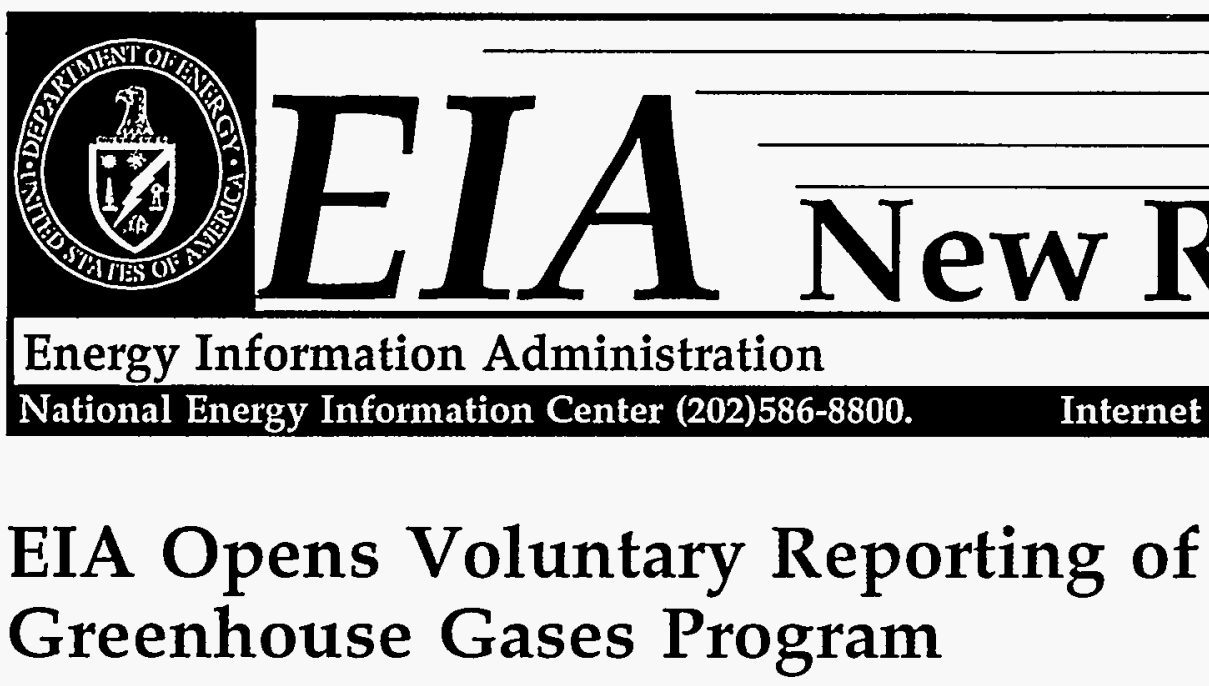

The Energy Information Administration (EIA) began accepting submissions for the Voluntary Reporting of Greenhouse Gases Program. Established under the Energy Policy Act of 1992, this voluntary reporting program affords an opportunity for any organization or individual to establish a public record of emissions, emission reductions, or sequestration achievements in a national, publicly available database.

Respondents can gain recognition for environmental stewardship while demonstrating their support for voluntary approaches to achieving environmental policy goals. By creating a readily accessible record of efforts to reduce emissions, the voluntary reporting program supports the exchange of information on the most effective ways to reduce greenhouse gas emissions and helps to inform the public debate about activities aimed at reducing or offsetting emissions. The voluntary reporting program accommodates reports covering any activity that reduces green-

\section{On the Inside}

\section{Data on Residential Energy Use} Available on Diskettes, Internet . . 2 Lingering Natural Gas Surplus Lowers Price-Expect Rebound ... 3 Coal Deliveries to Electric Utilities Hit Record Level . . . . . 4 Growth in U.S. Uranium Industry .. 4 Features and Press Releases ...... 5 Microfiched Products ........ 7 Electronic Publishing System .... 8 New Reports ............. 9 Machine-Readable Files ....... 12 How To Order EIA Publications . . 14 Energy Data Information Contacts .. 15 house gas emissions or increases carbon sequestration.

The reporting program emphasizes flexibility in the method of reporting and a comprehensive approach to what may be reported. Major features include:
\$
All Major Greenhouse Gases Cov- ered-information on all major green- house gases: carbon dioxide, methane, nitrous oxide, and halogenated sub- stances will be accepted.

ぬ (continued on page 2)
A Choice of Forms-reporters may choose to use either the long Form EIA- 1605 , designed to provide a detailed account of emissions, emission reduc- tions, and carbon sequestration, or the short Form EIA-1605EZ for reporters wishing to provide a brief synopsis of a project's emission reductions.

\section{U.S. Electric Utility Demand-Side Management Report Now Available}

Demand-side management (DSM) consists of electric utilities' planning, implementing, and monitoring of activities designed to encourage consumers to modify their level and pattern of electricity consumption to mutually benefit the utility, consumer, and society. Utilities implement DSM programs to achieve two basic objectives: energy efficiency and load management.

The Energy Information Administration's (EIA) latest study on DSM, U.S. Electric Utility Demand-Side Management 1993, provides a background of electric utility demand-side management in the United States and summarizes pertinent statistics for large utilities. The report is available from the U.S. Government Printing Office (202/512-1800) or from EIA's National Energy Information Center (202/586-8800).

Released for Printing: October 2, 1995 


\section{Data on Residential Energy Use Available on PC Diskettes and Internet}

Residential energy consumption and expenditures data and household characteristics information for 7,041 residential households in single-family units, mobile homes, and apartments from the 48 conterminous States and the District of Columbia are now available on personal computer diskettes and via Internet (http://www.eia.doe.gov). These data are from the 1993 Residential Energy Consumption Survey (RECS)-the ninth in a series that began in 1978-conducted by the Energy Information Administration.

The diskettes contain information on the physical characteristics of the housing unit, demographic information about the household, annualized 1993 fuel consumption and expenditures, and energy end use estimates for space heating, air conditioning, water heating, refrigerators, freezers, electric clothes dryers, dishwashers, electric cooking, other appliances, and lighting.

The smallest unit of analysis is the household; the finest geographic identification available are the nine Census divisions (groups of three to eight States). An exception to this are households in the four most populous States: California, Florida, New York, and Texas. For the first time, the 1993 RECS was designed to produce estimates of energy consumption arid expenditures in these four States.

Other new topics for the 1993 RECS are emerging technologies, consumer decision making regarding equipment purchases, additional appliance information, and home office equipment information. A Lighting Supplement was collected from approximately 500 households detailing the usage of lights and the types of lighting found in homes. Because previous estimates of lighting usage in residences vary greatly, these additional data will be very useful in identifying household lighting needs.

It is intended that the diskettes be used in conjunction with the following RECS publications:

Housing Characteristics 1993, DOE/EIA-0314(93) Household Energy Consumption and Expenditures, DOE/EIA-0321(93) (available late fall).
The report Housing Characteristics 1993 is available now from the U.S. Government Printing Office (GPO) (202/512-1800). Household Energy Consumption and Expenditures 1993, once published, will also be available from GPO.

The diskettes are available from the following:

National Technical Information Service Computer Products Division

5285 Port Royal Road

Springfield, VA 22161

(703)487-4650; Fax: (703)321-8547

or:

Office of Scientific and Technical

Information

Request Services

P. O. Box 62

Oak Ridge, TN 37831

(615)576-8401

For any questions, please call EIA's National Energy Information Center on (202)586-8800.

\section{Greenhouse Gases Program}

(continued from page 1)

Flexible and Modular Design-Form EIA-1605 includes separate and distinct areas for reporting baseline emissions for 1987-1990; entity-wide emissions and reductions for 1991 onwards; and emission reductions from projects such as tree planting, carpooling, demand-side management, and recycling.

Electronic Reporting-both forms are available in an electronic version that may be submitted on diskette through the U.S. mail or by transferring the file via modem.

The contents of the reports received by EIA will be summarized in a publication to be released in the spring of 1996.

For more information or copies of the reporting forms call 1-800-803-5182, send an e-mail message to infoghg@eia.doe.gov, or write to:

Voluntary Reporting of Greenhouse Gases Program; Energy Information Administration, EI-81; 1000 Independence Avenue, SW; Washington, DC 20585. (EIA Press Release EIA-95-15, July 19, 1995.) 


\section{DISCLAIMER}

Portions of this document may be illegible in electronic image products. Images are produced from the best available original document. 


\section{Lingering Natural Gas Surplus Lowers Price- Rebound Expected With Normal Winter Weather}

The Energy Information Administration (EIA) projects an 8-percent decline in the price of natural gas this year as a result of excess supply left by the mild 1994-1995 winter. According to the Short-Term Energy Outlook, released in August, the excess supply should be worked off by year-end, allowing prices to rebound. Assuming that demand increases as a result of normal weather next winter, EIA expects the 1996 average wellhead price of natural gas to surpass the 1994 level of $\$ 1.82$ per thousand cubic feet. However, the price recovery may be limited by the enhancement of natural gas productive capacity over the next year and a half.

EIA also projects that crude oil prices will increase by about $\$ 1.65$ per barrel in 1995 compared to 1994; however, this movement is seen largely as an adjustment to the low crude oil prices in 1994. Continued world demand growth through 1996 (about 1.6 percent per year) should drive production increases from OPEC and nonOPEC sources. Average 1996 crude oil prices may be slightly above 1995 levels, but no steep increases are anticipated under the base case.

Other statistics from the EIA quarterly report Short-Term Energy Outlook include:

Distillate fuel demand is expected to rise by just over 100,000 barrels per day in the fourth quarter 1995 compared to the fourth quarter 1994. Higher demand and more modest stock levels lead to an expected increase in distillate prices this fall, with retail heating oil rising about 7 cents per gallon over the fourth quarter 1994 average.

* The natural gas storage surplus is diminishing. Low heating demand due to the mild temperatures of this past winter resulted in relatively high natural gas storage levels, which, at the end of the season, were estimated to be 385 billion cubic feet higher than in 1994. However, a slower rate of storage injection this summer reduced the storage surplus to
85 billion cubic feet on July 1 compared with July 1, 1994, and gas storage levels should be close to the 1994 level in the second half of 1995.

Gasoline demand growth remains solid as efficiency improvements slip. First quarter 1995 highway travel grew by 3.8 percent over last year's level, although some of this increase reflected the effects of poor driving conditions in January and February 1994. For the year, travel demand growth will not remain so robust, but is expected to average 2.6 percent in 1995 and 1996. Meanwhile, the average miles per gallon achieved by the average car on the road appears to be growing at less than 1 percent per year, leading to record gasoline consumption levels.

Nuclear and hydropower generation of electricity are rising rapidly in 1995. Growing demand for electricity will primarily be met by increases in nuclear and hydroelectric generation in 1995, edging out fossil fuel generation, particularly in the utility sector. Normal precipitation in the Northwest has improved water conditions after the drought of the past few years. In 1996, however, continued growth in the demand for electricity is expected to be met largely by coal since hydroelectric growth is expected to be down from 1995 levels.

The Short-Term Energy Outlook provides quarterly short-term energy supply, demand, and price projections for publication in February, May, August, and November. It is prepared by the Energy Information Administration, Office of Energy Markets and End Use.

Copies of the report are available from the U.S. Government Printing Office (202/512-1800) or from EIA's National Energy Information Center (202/586-8800, E-Mail: infoctr@eia.doe.gov).

(EIA Press Release 95-20, August 10, 1995.)
Visit EIA's Home Page for latest energy data and news! http://www.eia.doe.gov 


\section{Coal Deliveries to Electric Utilities Hit Record Levels}

Electric utilities received a record 832 million short tons of coal in 1994, up 63 million short tons from 1993, according to a report released by the Energy Information Administration (EIA). At the same time, the average cost of coal continued the downward trend that began in 1985.

Coal deliveries to utilities eclipsed the previous high of 787 million short tons received in 1990, as utilities rebuild stocks from their lowest beginning-of-year levels in nearly two decades. Weather, labor disputes, and planned stock reductions by some utilities were factors in the abnormally low stock levels.

Lower costs were due, in part, to excess coal production capacity over the last several years. The excess production capacity has resulted in a "buyers' market" where supply continues to stay ahead of demand.

Also, utilities continued to increase their use of low-cost subbituminous coal from the Powder River Basin of Wyoming and Montana. Electric utilities throughout the West, Midwest, and in the South (as far east as Georgia and Florida) now use large amounts of Powder River Basin coal. Rail shipments of low-sulfur western coal increased as utilities conducted test-burns in preparation for the January 1, 1995 start of Phase I emission restrictions under the Clean Air Act Amendments.

The Energy Information Administration's (EIA) report, Cost and Quality of Fuels for Electric Utility Plants 1994, provides the most recent annual statistics available on the quantity, quality, and cost of fossil fuels used to produce electricity. The report discusses factors affecting supply, including the effects of extreme weather conditions and rail traffic congestion in the West on fuel deliveries. It includes information on imports and changes in origins and destinations of utility fuels.

Other report highlights:

In 1994, electric utilities received coal at a rate of 2.3 million short tons per day, an amount equivalent to the coal hauling capacity of approximately 23,000 rail cars.
* Receipts of petroleum fell to 143 million barrels and comprised only 4 percent of the total Btu delivered to electric utilities.

* Gas receipts by utilities in California climbed to 595 billion cubic feet in 1994, in response to a substantial decrease in hydroelectric generation caused by below-normal precipitation in the western United States.

Receipts of coal from the Powder River Basin totaled a record 248 million short tons, up from 220 million short tons in 1993.

Electric utilities paid $\$ 32$ billion for fossil fuels delivered in 1994.

Copies of the report are available from the U.S. Government Printing Office (202/512-1800) or through EIA's National Energy Information Center (202/586-8800). (EIA Press Release EIA-9515 , July 25, 1995.)

\section{U.S. Uranium Industry Shows Modest Growth in 1994}

U.S. uranium concentrate production increased by 9 percent in 1994 over the 1993 total, according to a report released by the Energy Information Administration (EIA). At 3.4 million pounds of uranium oxide $\left(\mathrm{U}_{3} \mathrm{O}_{8}\right)$, production has declined dramatically from a peak of 43.7 million pounds in 1980, due to oversupply and intense international competition. In response, the U.S. uranium industry has downsized and adopted less costly and more efficient production methods.

Some highlights from the Uranium Industry Annual 1994 include:

Concentrate shipments from U.S. production facilities were 6.3 million pounds during 1994, an increase of 87 percent over the 1993 level, as producers lowered their stocks of uranium.

Employment in the raw materials sector of the industry increased during 1994 by 19 percent to 452 persons.

New uranium fuel assemblies loaded into U.S. commercial nuclear reactors during 1994 accounted for 39.0 million pounds $\mathrm{U}_{3} \mathrm{O}_{8}$. (continued on page 6) 
Reprints of special features (Feature Articles, Highlights, Energy Previews, EIA Data News, etc.) appearing in Energy Information Administration (EIA) reports are available free from the National Energy Information Center.
Below is a listing of the features published so far in 1995. For a listing of features published in 1994, please refer to the November-December issue of EIA New Releases, DOE/EIA-0204(94/06). to

\section{Feature (Publication}

Highlights: Manufacturing Consumption of Energy 1991 (Monthly Energy Review)

Feature Article: U.S. Wind Energy Potential: The Effect of the Proximity of Wind Resources to Transmission Lines (Monthly Energy Review)

Feature Article: The Comparability of Resource and Reserve Data for Crude Oil, Natural Gas, Coal, and Uranium (Natural Gas Monthly and Petroleum Supply Monthly)

EIA Data News: The Response Analysis Survey: Evaluating Manufacturing Energy

Consumption Survey Methodology (Montlly Energy Review)

Feature Article: Comparisons of Independent Statistics on Petroleum Supply

(Petroleum Supply Monthly)

Highlights: Commercial Buildings Energy Consumption and Expenditures 1992

(Monthly Energy Review)

Energy Preview: Electric Utility Fleet Survey 1993, Preliminary Estimates (Monthly Energy Review)

Feature Article: Summer 1995 Gasoline Assessment (Petroleum Marketing Monthly and Petroleum Supply Monthly)

Feature Article: Summer Outlook for Motor Gasoline (Short-Term Energy Outlook, Quarterly Projections, Second Quarter)

Feature Article: The Comparability of Resource and Reserve Data or Crude Oil, Natural Gas, Coal, and Uranium (Quarterly Coal Report October-December 1994, Fourth Quarter)

Feature Article: What Drives Motor Gasoline Prices? (Petroleum Marketing Monthly)

Feature Article: Comparison of Uranium Mill Tailings Reclamation in the United States (Uranium Industry Annual 1994)

Feature Articles: The Status of U.S. Electric Utility Demand-Side Management and

Evaluation and Verification of Demand-Side Management Programs (U.S. Electric Utility Demand-Side Management 1993)

Feature Article: Revisions to Monthly Natural Gas Data (Natural Gas Monthly)

Feature Article: Nonutility Electric Generation: Industrial Power Production (Electric

Power Monthly)

Feature Article: Steam Generator Degradation and its Impact on Continued Operation of

Pressurized Water Reactors in the United States (Electric Power Monthly)

Feature Article: U.S. Natural Gas Imports and Exports-1994 (Natural Gas Monthly)

Feature Article: Measuring Dependence on Imported Oil (Monthly Energy Review)
Published Date:

January 1995

February 1995

March 1995

March 1995

April 1995

April 1995

April 1995

May 1995

May 1995

May 1995

June 1995

July 1995

July 1995

July 1995

July 1995

August 1995

August 1995

August 1995

t

Periodically, the Energy Information Administration (EIA) issues press releases on current, highinterest issues. Copies of these releases are available from NEIC (202/586-8800).
Below is a listing of all EIA press releases prepared by EIA since the beginning of 1995 . For a listing of all 1994 press releases, see EIA New Releases, DOE/EIA-0204(94/06).

\section{Press Release Title}

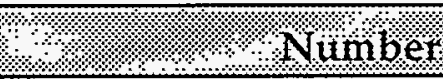

Full Report Assesses the Oil and Gas Resources of Fergana Basin, Former Soviet Union

Improved Technology Leads to Lower Energy Price Projections

EIA-95-01

Date Issured

Internet, Bulletin Board Speed Access to EIA's Short-Term Energy Model

EIA-95-02

$01 / 06 / 95$

(continued on next page) 


\begin{tabular}{|c|c|c|}
\hline Press Release Irtie (contal) & Number & Paterissured \\
\hline $\begin{array}{l}\text { Major Energy Companies' Strategies After Arab Oil Embargo } \\
\text { Shift from Growth to Consolidation }\end{array}$ & EIA-95-04 & $01 / 31 / 95$ \\
\hline Reliability and the Changing Electric Power Industry & EIA-95-05 & $02 / 01 / 95$ \\
\hline $\begin{array}{l}\text { Natural Gas Wellhead Prices Expected To Remain Low in First } \\
\text { Half } 1995\end{array}$ & EIA-95-06 & $02 / 15 / 95$ \\
\hline $\begin{array}{l}\text { EIA Examines the Decommissioning of the U.S. Uranium } \\
\text { Production Facilities }\end{array}$ & EIA-95-07 & $02 / 23 / 95$ \\
\hline EIA Updates Reference on U.S. Coal & EIA-95-08 & $02 / 27 / 95$ \\
\hline EIA Examines the Growing Importance of Longwall Mining & EIA-95-09 & $03 / 23 / 95$ \\
\hline EIA Provides a Nation-by-Nation Overview of Global Energy Markets & EIA-95-10 & $05 / 11 / 95$ \\
\hline $\begin{array}{l}\text { Gasoline Price Changes To Have Little Impact on Consumption } \\
\text { During Summer Driving Season }\end{array}$ & ELA-95-11 & $05 / 12 / 95$ \\
\hline $\begin{array}{l}\text { OPEC Supply of World Oil Projected To Rise to } 52 \text { Percent by 2010; } \\
\text { Electricity Use To Drive Growth in World Energy Demand }\end{array}$ & EIA-95-12 & $06 / 14 / 95$ \\
\hline EIA Details Changes in Household Energy Use & EIA-95-13 & $06 / 12 / 95$ \\
\hline Building Space, Use of Home Appliances Grew Rapidly in the 1980's & EIA-95-14 & $06 / 29 / 95$ \\
\hline $\begin{array}{l}\text { Energy Information Administration Opens Voluntary Reporting of Greenhouse } \\
\text { Gases Program }\end{array}$ & EIA-95-15 & $07 / 19 / 95$ \\
\hline Coal Deliveries to Electric Utilities Hit Record Levels & EIA-95-16 & $07 / 25 / 95$ \\
\hline U.S. Uranium Industry Shows Modest Growth in 1994 & EIA-95-17 & $07 / 25 / 95$ \\
\hline $\begin{array}{l}\text { EIA Reports Increased Shipments, Lower Prices of Photovoltaic Cells and } \\
\text { Modules }\end{array}$ & EIA-95-18 & $07 / 27 / 95$ \\
\hline $\begin{array}{l}\text { Natural Gas Use for Electricity Generation on the Rise at U.S. Electric } \\
\text { Utilities }\end{array}$ & EIA-95-19 & $08 / 01 / 95$ \\
\hline $\begin{array}{l}\text { Lingering Natural Gas Surplus Lowers Price; Rebound Expected With Normal } \\
\text { Winter Weather }\end{array}$ & EIA-95-20 & $08 / 10 / 95$ \\
\hline U.S. Natural Gas Reserves Up; First Gain in Four Years & EIA-95-21 & $08 / 21 / 95$ \\
\hline
\end{tabular}

to

\section{U.S. Uranium Industry Shows Modest Growth in 1994}

(continued from page 4)

Utilities took delivery of $\mathbf{3 8 . 3}$ million pounds $\mathrm{U}_{3} \mathrm{O}_{8}$ in 1994, at an average price of $\$ 10.40$ per pound. Domestic-origin uranium accounted for 7.7 million pounds (20 percent of total deliveries) at an average price of $\$ 12.08$ per pound. The remaining 30.6 million pounds was of foreign origin, at an average price of $\$ 9.97$ per pound.

Uranium inventories held by U.S. utilities at year-end 1994 decreased 14.4 million pounds $\mathrm{U}_{3} \mathrm{O}_{8}$ from the year-end 1993 level. This was the 11th straight year of declining utility inventories.
U.S. utilities sold 5.2 million pounds of inventories to U.S. and foreign suppliers during 1994, and another 9.6 million pounds were loaned.

The Uranium Industry Annual 1994 includes an article, "Comparison of Uranium Mill Tailings Reclamation in the United States and Canada," which examines the technical approach to site remediation in the two countries. Copies of the report are available from the Government Printing Office (202/512-1800), or through EIA's National Energy Information Center (202/586-8800).

(EIA Press Release EIA-95-17, July 25, 1995.) 
Microfiched Model and System Documentation

The Energy Information Administration (EIA) model and system documentation reports are available in microfiche form; the agency does not formally print or distribute this category of reports. The Department of Energy's Office of Scientific and Technical Information (OSTI) in Oak Ridge, Tennessee, produces these reports in microfiche form and sends the microfiche to the
National Technical Information Service (NTIS). NTIS sells these documents in microfiche or hard-copy form upon request.

Following is a listing of all EIA reports that have been released to OSTI since the beginning of 1995. Future editions of EIA New Releases will provide updates on the latest available reports. For more information, contact the National Energy Information Center (NEIC) by telephone on (202)586-8800 or on Internet (infoctr@eia.doe.gov). (4)

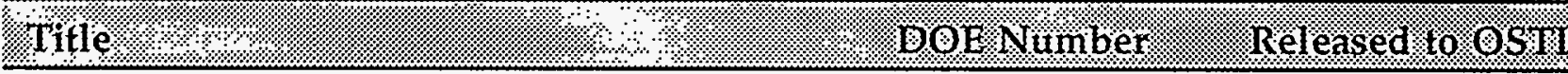

Model Documentation, Natural Gas Transmission and Distribution Model (NGTDM) of the National Energy Modeling System, Volume II: Model Developer's Report

Documentation of the Petroleum Market Model (PMM) Appendix: Model Developer's Report

Model Documentation, Renewable Fuels Module of the National Energy Modeling System, Appendix: Model Performance

Documentation of the Oil and Gas Supply Module (OGSM) Appendix: Model Developers Report

Model Developer's Appendix to the Model Documentation Report: NEMS Macroeconomic Activity Module Model Documentation Report: Residential Sector Demand Module of the National Energy Modeling System Model Documentation Natural Gas Transmission and Distribution Model of the National Energy Modeling System, Volume I

Model Documentation Electricity Market Module Modifications to the Electricity Capacity

Planning Submodule

Model Documentation Coal Market Module of the National Energy Modeling System

NEMS Integrating Module Documentation Report

Documentation of the Electricity Market Module (EMM) Appendix: Model Developers Report

EIA Model Documentation: Petroleum Market Model of the National Energy Modeling System

Model Documentation: Renewable Fuels Module of the National Energy Modeling System
DOE/EIA-M062/2

January 1995

DOE/EIA-M059/A

January 1995

DOE/EIA-M069/A

January 1995

DOE/EIA-M063A(95)

March 1995

DOE/EIA-M065A(95)

March 1995

DOE/EIA-M067(95)

March 1995

DOE/EIA-M062/1(95)

March 1995

DOE/EIA-M068-B/1

April 1995

DOE/EIA-M060(95)

April 1995

DOE/EIA-M057(95)

May 1995

DOE/EIA-M068(95)Appx. June 1995

DOE/EIA-M059(95)

August 1995

DOE/EIA-M069(95)

August 1995 


\section{Electronio ?ablishing System EAPIB}

EPUB is an electronic publishing system maintained by the Energy Information Administration (EIA) of the U.S. Department of Energy. EPUB allows the general public to electronically access selected energy data from many of EIA's statistical reports. The system is a menu-driven, bulletin-board-type system with extensive online help capabilities that can be accessed free of charge 24 hours a day by using a terminal or PC with an asynchronous modem. (EPUB will be taken down briefly at midnight for backup.)

PC users must provide the following information to their communications software in order to successfully access the EPUB system:

Communications Parameters:

Baud Rate: Up to 28,800 bps

Data Bits: 8; Stop Bits: 1

Parity: None; Duplex: Full

Terminal Type: ANSI, ANSI-BBS, VT100, etc.

Once communications software and/or hardware have been configured, EPUB can be accessed by dialing (202)586-2557. When a connection to the system has been made, some users may find that the menu-driven instructions and the online capabilities will provide enough information to effectively use EPUB. More information may be obtained from:

National Energy Information Center, EI-231

Energy Information Administration

Forrestal Building, Room 1F-048

Washington, DC 20585

(202)586-8800

Internet E-Mail: infoctr@eia.doe.gov

TTY: For people who are deaf or

hard of hearing: (202)586-1181

Hours: 9 a.m. to 5 p.m., M-F, eastern time
For communications or technical assistance, call (202)586-8959, 8 a.m. to 5 p.m. eastern time, Monday through Friday. For questions about the contents of EPUB reports and data, call (202)5868800,9 a.m. to 5 p.m., Monday through Friday, eastern time.

Following is a listing of some of the data and reports that are provided on EPUB:

Heating fuel data (April through September) Updated the second week of the month.

Oxygenate data Updated approximately the 25th of the month.

Weekly Petroleum Status Report

Updated on Wednesdays (Thursdays in the event of a holiday) at 9 a.m.

Petroleum Supply Monthly

Updated between the 23rd and 26th of the month.

Petroleum Marketing Monthly

Updated on the 20th of the month.

Natural Gas Monthly

Updated on the 20th of the month.

Weekly Coal Production

Updated on Fridays by 5 p.m.

Quarterly Coal Report

Updated 60 days after the end of the quarter.

Electric Power Monthly

Updated during the first week of the month.

Monthly Energy Review

Updated the last week of the month.

Short-Term Energy Outlook

Updated 60 days after the end of the quarter.

Winter Fuels Report (October through March). Propane inventory and distillate data updated Wednesdays at 5 p.m. All other data updated Thursdays (Friday in event of a holiday) at 5 p.m.

\section{Internet Access to EPUB}

The EPUB system is not as yet directly accessible via Internet. However, Internet users can access EPUB via the FEDWORLD electronic bulletin board operated by the National Technical Information Service, U.S. Department of Commerce. The Internet address for FEDWORLD is FEDWORLD.GOV. Select "GATEWAY" from the main menu, and EPUB will be item 16 on that list. 


\section{Muilitisounce Energy}

\section{Monthly Energy Review}

This top-selling monthly publication presents a complete overview of the Nation's energy picture. It provides data on petroleum, natural gas, coal, electricity, nuclear energy, oil and gas resource development, prices, consumption, and the international energy situation. Appendices present thermal, metric, and other physical conversion factors.

DOE/EIA-0035(95/07), 184 pp., July 1995

DOE/EIA-0035(95/08), 196 pp., August 1995

Annual Subscription:

Domestic, $\$ 80.00$; Foreign, $\$ 100.00$

Single Issue: Domestic, \$12.00; Foreign, $\$ 15.00$

\section{Short-Term Energy Outlook}

\section{Quarterly Projections}

This report discusses macroeconomic activities; the outlook for petroleum demand, supply, and product prices; world oil prices; and outlooks for other major energy sources (natural gas, coal, and electricity).

The forecast period for this issue extends from the third quarter of 1995 through the fourth quarter of 1996. Values for the second quarter of 1995, however, are preliminary EIA estimates.

DOE/ELA-0202(95/3Q), 56 pp., August 1995

Annual Subscription:

Domestic, \$17.00; Foreign, \$21.25

Single Issue: Domestic, \$4.75; Foreign, \$5.94

\section{Short-Term Energy Outlook Annual Supplement 1995}

This report is published once a year as a complement to the Short-Term Energy Outlook (Outlook), Quarterly Projections. The purpose of the report is to review the accuracy of the forecasts published in the Outlook, make comparisons with other independent energy forecasts, and examine current energy topics that affect the forecasts.

DOE/EIA-0202(95), 96 pp., July 1995

GPO Stock No. 061-003-00915-8

Domestic, $\$ 6.00$; Foreign, $\$ 7.50$

\section{One-Time Reports}

\section{U.S. Electric Utility Demand-Side Management 1993}

The report presents comprehensive information on electric power industry demand-side management (DSM) activities in the United States at the national, regional, and utility levels. (DSM consists of electric utilities' planning, implementing, and monitoring of activities designed to encourage consumers to modify their level and pattern of electricity consumption to mutually benefit the utility, consumer, and society.)

DOE/EIA-0589(93), 136 pp., July 1995

GPO Stock No. 061-003-00922-1

Domestic, \$9.00; Foreign, \$11.25

This report was prepared by the Energy Information Administration, the independent statistical and analytical agency within the U.S. Department of Energy. The information contained herein should not be construed as advocating or reflecting any policy position of the U.S. Department of Energy or of any other organization.

EIA New Releases is published six times per year and is available free of charge to anyone who requests it. Ask to be added to our mailing list by using the order form on the last page, by calling the EIA's National Energy Information Center (NEIC) on (202) 586-8800 (open 9 a.m. to 5 p.m., Monday through Friday, eastern time), or by contacting us on Internet. Our e-mail address is:

$$
\text { infoctr@eia.doe.gov. }
$$

This report is also available electronically from the following:

EPUB, EIA's electronic bulletin board (see page 8 for access information)

EIA's World Wide Web site for Internet users (http://www.eia.doe.gov)

Inquiries or comments concerning the contents of this publication should be directed to the editor Ingrid Springer at (202)5861100; all questions about EIA information should be directed to NEIC. 


\section{Petroleum}

\section{Weekly Petroleum Status Report}

This weekly report, published each Wednesday, provides timely data on petroleum supply and disposition (includes propane stocks). The data are based on company submissions for the week ending at 7 a.m. the preceding Friday.

DOE/EIA-0208(95-27)-(95-35) varied page count July through August 1995

Annual Subscription:

Domestic, $\$ 65.00$; Foreign, $\$ 81.25$

Single Issue: Domestic, $\$ 3.50$; Foreign, $\$ 4.38$

\section{International Petroleum Statistics Report}

This report contains current international data on oil production, consumption, imports, exports, and stocks.

DOE/EIA-0520(95/07), 84 pP., July 1995

DOE/EIA-0520(95/08), 84 Pp., August 1995

Annual Subscription:

Domestic, $\$ 52.00$; Foreign, $\$ 65.00$

Single Issue: Domestic, $\$ 5.50$; Foreign, $\$ 6.88$

\section{Petroleum Marketing Monthly}

This publication provides price information on a variety of petroleum products, including motor gasoline, distillate fuel oil, jet fuels, kerosene, and propane. Sales data for petroleum products are also included.

DOE/ELA-0380(95/07), 208 pp., July 1995

DOE/ELA-0380(95/08), 208 pp., August 1995

Annual Subscription:

Domestic, $\$ 84.00$; Foreign, $\$ 105.00$

Single Issue: Domestic, $\$ 14.00$; Foreign, $\$ 17.50$

\section{Petroleum Supply Monthly}

This publication provides monthly statistics on petroleum supply, disposition, production, refinery operations, stocks, and transport.

DOE/ELA-0109(95/07), 172 pp., July 1995 DOE/EIA-0109(95/08), 176 pp., August 1995

Annual Subscription:

Domestic, \$83.00; Foreign, $\$ 103.75$

Single Issue: Domestic, \$12.00; Foreign, $\$ 15.00$

\section{Petroleum Marketing Annual 1994}

This report provides information and statistics on a variety of crude oils and refined petroleum products and presents data on crude oil costs and refined petroleum products sales.

DOE/EIA-0487(94), 508 pp., August 1995

GPO Stock No. 061-003-00923-9

Domestic, $\$ 32.00$; Foreign, $\$ 40.00$

\section{Electricity}

\section{Electric Power Monthly}

This report presents monthly statistics at the national, Census division, State, and U.S. levels for net generation, fossil fuel consumption and stocks, quantity, quality, and cost of fossil fuels, electricity sales, revenue, and average revenue per kilowatthour of electricity sold.

DOE/EIA-0226(95/07), 216 pp., July 1995

DOE/EIA-0226(95/08), 220 pp., August 1995

Annual Subscription:

Domestic, $\$ 87.00$; Foreign, $\$ 108.75$

Single Issue: Domestic, $\$ 14.00$; Foreign, $\$ 17.50$

\section{Cost and Quality of Fuels for} Electric Utility Plants 1994

This report presents an annual summary of statistics at the national, Census division, State, electric utility, and plant levels regarding the quantity, quality, and cost of fossil fuels used to produce electricity.

DOE/EIA-0191(94), 176 pp., July 1995

GPO Stock No. 061-003-00921-2

Domestic, $\$ 12.00$; Foreign, $\$ 15.00$

\section{Electric Power Annual 1994 Volume I}

This volume contains final 1994 data on net generation and fossil fuel consumption, stocks, receipts, and costs; generating unit capability and planned additions; and estimates of retail sales of electricity, associated revenue, and the average revenue per kilowatthour of electricity sold.

DOE/EIA-0348(94)/1, 76 pp., July 1995

GPO Stock No. 061-003-00920-4

Domestic, \$5.00; Foreign, $\$ 6.25$ 


\section{Coal Reports}

\section{Weekly Coal Production}

This short report provides timely information on coal production, as estimated by the EIA from railroad car loadings.

DOE/EIA-0218(95-26)-(95-33), varied page count

July through August 1995

Annual Subscription:

Domestic, $\$ 85.00$; Foreign, $\$ 106.25$

Single Issue: Domestic, $\$ 2.00$; Foreign, $\$ 2.50$

\section{Quarterly Coal Report}

\section{January-March 1995}

This report provides information about U.S. coal production, distribution, exports, imports, receipts, prices, consumption, and stocks. Also provided are coke production, consumption, distribution, and imports and exports data.

DOE/EIA-0121(95/1Q), 160 pp., August 1995

Annual Subscription:

Domestic, $\$ 26.00$; Foreign, $\$ 32.50$

Single Issue: Domestic, \$11.00; Foreign, $\$ 13.75$

\%. Techinical Reports

\section{State Energy Severance Taxes} 1985-1993

This report analyzes changes in aggregate and State-level energy severance taxes for 1985 through 1993. Data are presented for crude oil, natural gas, and coal. The report highlights trends in severance tax receipts relative to energy prices and production.

DOE/EIA-TR-0599, 24 pp., August 1995

GPO Stock No. 061-003-00924-7

Domestic, $\$ 2.00$; Foreign, $\$ 2.50$

NOTE: In some instances, the month shown here may not correspond with the month shown on the cover or spine of a report. EIA New Releases lists the month that a report is RELEASED to the printer. However, some EIA report covers and spines display the date when the report is AVAILABLE to the public.

\section{Metadata.}

\section{EIA Publications Directory 1994}

This directory contains abstracts and ordering information for individual issues of semiannual, annual, biennial, and triennial EIA periodicals, analysis reports, service reports, and model documentations published in 1994 by the Energy Information Administration.

DOE/ELA-0149(94), 68 pp., July 1995

\section{Directory of Energy Information Administration Models 1995}

This report contains descriptions of EIA models, including the title, acronym, and purpose, followed by more detailed information on characteristics, uses, and requirements. Until now, the report has been published annually; however, after this issue, it will only be published biennially.

DOE/EIA-0293(95), 96 pp., July 1995

EIA Directories are free from the National Energy Information Center (NEIC). Call NEIC at (202)586-8800 to request a copy.

\section{Natural Gas}

\section{Natural Gas Monthly}

This report provides information on the supply and disposition of natural gas, including production, storage, import, export, and consumption data and provides information on the activities of major interstate pipeline companies.

DOE/EIA-0130(95/07), 136 pp., July 1995

DOE/EIA-0130(95/08), 136 pp., August 1995

Annual Subscription:

Domestic, \$77.00; Foreign, $\$ 96.25$

Single Issue: Domestic, $\$ 8.00$; Foreign, $\$ 10.00$

Please see page 13 for continuation of reports listing. 
The Energy Information Administration (EIA) makes its machine-readable data files and modeling programs available through the National Technical Information Service (NTIS) (703)4874650. For a description of EIA's machine-readable products, contact the National Energy Information Center (NEIC) at (202)586-8800 (Internet E-Mail: infoctr@eia.doe.gov) and request a copy of the EIA Directory of Electronic Products.
Data and model diskettes are available from the Department of Energy's Office of Scientific and Technical Information (OSTI). To order, call OSTI at (615)576-8401 and reference the diskettes by title.

Listed below are the most recently updated data files made available from NTIS and OSTI. \%

\section{NTIS}

\begin{tabular}{|c|c|c|c|}
\hline Nris Norder & Erequency & Tine & Ooutes of \\
\hline PB93-592450 & Monthly & Monthly Power Plant Report (diskette) & $01 / 95-05 / 95$ \\
\hline PB91-591650 & Monthly & Monthly Energy Review Data Base (diskette) & $1973-07 / 95$ \\
\hline PB93-592460 & Monthly & $\begin{array}{l}\text { Monthly Electric Utility Sales and Revenue Report } \\
\text { (diskette) }\end{array}$ & $01 / 95-05 / 95$ \\
\hline PB95-* & Triennial & $\begin{array}{l}\text { Commercial Buildings Energy Consumption, } \\
\text { Consumption and Expenditures } 1992 \text { (diskette) }\end{array}$ & 1992 \\
\hline PB95-* & Triennial & $\begin{array}{l}\text { Residential Energy Consumption Survey } 1993 \\
\text { (diskette) }\end{array}$ & 1993 \\
\hline PB95-* & One-Time & Buildings and Energy in the 1980's (diskette) & 1980-1989 \\
\hline PB95-* & Annual & Annual Energy Review 1994 (diskette) & 1994 \\
\hline PB95-* & Annual & $\begin{array}{l}\text { Annual Report of Major U.S. Investor-Owned } \\
\text { Electric Utilities } 1993 \text { (diskette) }\end{array}$ & 1993 \\
\hline PB95-* & Annual & $\begin{array}{l}\text { Annual Report of Major U.S. Publicly-Owned } \\
\text { Electric Utilities } 1993 \text { (diskette) }\end{array}$ & 1993 \\
\hline
\end{tabular}

*Order number not available yet.

\section{OSTI (Diskettes)}

\begin{tabular}{|c|c|c|}
\hline Frequency & Titie & Dates ofof $:$ : \\
\hline Monthly & Monthly Energy Review Data Base & $1973-07 / 95$ \\
\hline Monthly & Monthly Power Plant Report & $01 / 95-05 / 95$ \\
\hline Monthly & Monthly Electric Utility Sales and Revenue Report & $01 / 95-05 / 95$ \\
\hline Annual & Annual Energy Review & 1994 \\
\hline Triennial & $\begin{array}{l}\text { Commercial Buildings Energy Consumption, } \\
\text { Consumption and Expenditures } 1992\end{array}$ & 1992 \\
\hline One-Time & Buildings and Energy in the 1980's & $1980-1989$ \\
\hline Triennial & Residential Energy Consumption Survey 1993 & 1993 \\
\hline Annual & $\begin{array}{l}\text { Annual Report of Major U.S. Investor-Owned } \\
\text { Electric Utilities } 1993\end{array}$ & 1993 \\
\hline Annual & $\begin{array}{l}\text { Annual Report of Major U.S. Publicly Owned Electric } \\
\text { Utilities } 1993\end{array}$ & 1993 \\
\hline
\end{tabular}

tots 
Reports listing continued from page 11:

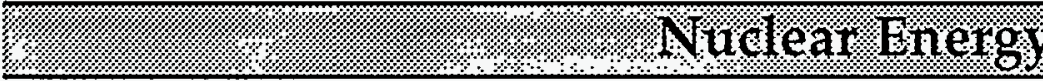

Uranium Industry Annual 1994

This report provides current statistical data on the U.S. uranium industry's activities relating to uranium raw materials and uranium marketing during that survey year.

DOE/EIA-0478(94), 132 pp., July 1995

GPO Stock No. 061-003-00916-6

Domestic, $\$ 11.00$; Foreign, $\$ 13.75$
Uranium Purchases Report 1994

This report presents U.S. utility purchases of uranium and enrichment services by origin country and seller.

DOE/EIA-0570(94), 12 pp., July 1995

GPO Stock No. 061-003-00912-2

Domestic, \$1.50; Foreign, \$1.88

For a complete listing of the Energy Information Administration's (EIA) reports published in 1994, refer to EIA's Publications Directory 1994. It is available, free of charge, from the National Energy Information Center at the following address and numbers:

National Energy Information Center

Energy Information Administration

EI-231, Forrestal Building

Washington, DC 20585

(202)586-8800

Internet E-Mail: infoctr@eia.doe.gov

TTY: (202) 586-1181

Hours: 9 a.m. to 5 p.m., M-F, eastern time. w

Please note that prices of EIA products sold by the U.S. Gopvernment Printing Office, the National Technical Information Service, or the Office of Scientific and Technical Information are subject to change without prior notice. 
Items listed in EIA New Releases can be ordered from one of four places: the National Energy Information Center (NEIC), the U.S. Government Printing Office (GPO), the National Technical
Information Service (NTIS), and the U.S. Department of Energy's Office of Scientific and Technical Information (OSTI). The chart below shows what can be ordered and from where.

Pirectories and EIA New Releases - current issues
Directories and EIA New Releases - back issues
For-sale publications - current issues
For-sale publications - back issues
Subscriptions
Machine-readable products

The category of publications called "Directories and EIA New Releases" is free to everyone. The category includes the following items: EIA New Releases, Energy Information Directory, EIA Directory of Electronic Products, EIA Publications Directory, Directory of Energy Data Collection Forms, Directory of Energy Information Model Abstracts, the Energy Information Administration's Annual Report to Congress, and all service reports and Energy Information Sheets. However, there is a charge for back issues from NTIS. (A current issue is one that is less than 1 year old.)

Publications and subscriptions normally for sale are free if ordered from NEIC by the following customers: Public, school, and university libraries; DOE contractors; employees of the media, Congress, and Federal, State, local, and foreign governments; and EIA survey respondents.

Subscriptions from GPO are available for weekly, monthly, and quarterly, but not for annual, publications.

\section{To Order from NEIC}

Contact us at (202)586-8800, TTY (202)586-1181, Internet E-Mail: infoctr@eia.doe.gov, or use the form entitled "NEIC Orders" in the back of this report. This form should also be used if you have changed your address or if you want your name removed from the mailing list.

\section{To Order from GPO}

Single-Issue Publications and Subscriptions: Call the GPO Main Order Desk at (202)512-1800 (FAX: (202)512-2250) or use the order form entitled "GPO Orders" in the back of this report.
GPO accepts the following types of payment: check or money order made out to the Superintendent of Documents, credit card number and expiration date for VISA or MasterCard, or a GPO deposit account number. To open such an account, call (202)783-3238. Payment must be included before an order can be filled.

\section{To Order from OSTI}

\section{Personal Computer Diskettes:}

Call Request Services at (615)576-8401 or send your order to the following address: Office of Scientific and Technical Information, Request Services, P.O. Box 62, Oak Ridge, TN 37831.

OSTI accepts the following types of payment: check or money order made out to the United States Department of Energy, or credit card number and expiration date for VISA or MasterCard. Payment must be included before an order can be filled.

\section{To Order from NTIS}

To order from NTIS, call (703)487-4650 or use the order form entitled "NTIS Orders" in the back of this report.

Reports are available from NTIS in hard copy, microfiche, or paper copy reproduced from microfiche.

NTIS accepts the following forms of payment: check or money order made out to NTIS, VISA, MasterCard, or American Express, or an NTIS deposit account number. To open an NTIS deposit account, call (703)487-4770. Requests will not be processed unless payment accompanies the order, except in the case of "ship-and-bill" orders. 
All telephone numbers are in area code 202, except where noted otherwise.

Each FAX number applies to all names that follow.

Each Internet name is followed with @eia.doe.gov

\begin{tabular}{|c|c|c|}
\hline Fueland.or Specific Orata A rea & (1) Name & Helephone \\
\hline
\end{tabular}

COAL:

Annual Mining and Production

Consumption

Distribution

Exports

Monthly Data

Producer/Distributor Stocks

Production and Consumption

Quarterly Data

Reserves

Short-Term Projections and Analysis

Stocks

Weekly Production

ELECTRIC POWER: Nonutility

Capacity, Generation, Energy Use (including renewables) and Sales to Grid

Nonutility Short-Term Projections and Analysis

ELECTRIC POWER: Utility

Clean Air Act Database

Demand-Side Management

Emissions

Imports

Short-Term Hydroelectric Projections

Utility Analysis

Utility Boiler Design

Utility Bulk Power Transmission, Including Imports

and Exports

Utility Capacity

Utility Repowering

Utility Life Extension

Utility Financial Data Systems

Utility Finance, Investor-Owned

Utility Finance, Publicly Owned

Utility Fuel Consumption

Utility Fuel Receipts

Utility Fuel Cost and Quality

Utility Fuel Stocks/Generation

Utility Power Production Expenses
FAX Number:

Fred Freme

Steve Scott

Mary Lilly

Tom Murphy

Paulette Young

Paulette Young

Tom Murphy

Mary Paull

Paulette Young

Richard Bonskowski

Willie Hong

Mary Paull

Mary Lilly

FAX Number:

Betty Williams

Robin Reichenbach

FAX Number:

Ron Hankey

Linda Bromley

John Colligan

Robin Reichenbach

Robin Reichenbach

Betsy O'Brien

John Colligan

John Makens

Elsie Bess

Karen McDaniel

Arthur Fuldner

Arthur Fuldner

Lucinda Gilliam

Jerry Sanderson

C. Harris-Russell

Melvin Johnson

Deborah Bolden

Kenny McClevey

Kenny McClevey

Melvin Johnson

Deborah Bolden

Elsie Bess
254-5765

254-5367

254-5467 sscott

254-5391 mlilly

254-5561 tmurphy

254-5481 pyoung

254-5481 pyoung

254-5561 tmurphy

254-5379 mpaull

254-5481 pyoung

254-5383 rbonskow

254-5365 bhong

254-5379 mpaull

254-5391 mlilly

254-5765

254-5656 bwilliam

254-5353 rreichen

254-5765

254-5333 rhankey

254-5653 lbromley

254-5465 jcolliga

254-5353 rreichen

254-5353 rreichen

254-5490 bobrien

254-5465 jcolliga

254-5629 jmakens

254-5637 ebess

254-5672 kmcdanie

254-5321 afuldner

254-5321 afuldner

254-5438 lgilliam

254-5463 jsanders

254-5437 charrisr

254-5665 mejohnso

254-5663 dbolden

254-5655 kmccleve

254-5655 kmccleve

254-5665 mejohnso

254-5663 dbolden

254-5637 ebess

(continued on next page) 
All telephone numbers are in area code 202, except where noted otherwise.

Each FAX number applies to all names that follow.

Each Internet name is followed with @eia.doe.gov

\section{Furel aridior Speciftec Bata Area \\ Electric Power: Utility (cont'd)}

Short-Term Hydroelectric Power Projections

Short-Term Electricity Imports Projections

Statistical Reports

Utility Sales and Revenue

NUCLEAR POWER:

Capacity and Generation

Domestic and Foreign Nuclear Power Capacity

and Generation

Foreign Nuclear Power

Fuel Cycle Requirements Projections

Short-Term Nuclear Generation Projections

Spent Fuel Projections

Waste Characteristics

Waste Fund Fees

\section{URANIUM:}

Decommissioning

Demand/Requirements

Exploration and Industry Employment

Marketing, Imports/Exports

Production, Prices

Resources/Reserves

RENEWABLE ENERGY:

Alternative-Fueled Vehicles

Alternative Transportation Fuels

Biomass/Biofuels

Geothermal

Renewable Resources Assessment

Solar Collector, Photovoltaic

Solar Collector Cells/Modules

NATURAL GAS:

Coalbed Methane/Tight Gas

Consumer and City Gate Prices

Consumption (by sector)

Drilling

Exploration

Futures Market

Imports/Exports
Name

FAX Number:

Robin Reichenbach

Robin Reichenbach

Sandra Smith

Lucinda Gilliam

Deborah Bolden

Stephen Calopedis

Linda Bromley

Trtephone Trternet

254-5765

254-5353

254-5353

254-5632

254-5438

254-5663

254-5661

254-5653

rreichen

rreichen

ssmith

lgilliam

dbolden

scaloped

Ibromley

FAX Number:

254-5765

$\begin{array}{lll}\text { Doug Bonnar } & 254-5560 & \begin{array}{l}\text { dbonnar } \\ \text { Kwade }\end{array} \\ \text { Douneth C. Wade } & 254-5514 & \\ \text { Diane Jackson } & 254-5560 & \begin{array}{l}\text { dbonnar } \\ \text { djackson }\end{array} \\ \text { Kenneth C. Wade } & 254-5536 & \text { kwade } \\ \text { Diane Jackson } & 254-5514 & \text { djackson } \\ \text { Kathy Gibbard } & 254-5536 & \text { kgibbard } \\ \text { John Howie } & 254-5439 & \text { jhowie }\end{array}$

FAX Number:

254-5765

Taesin Chung

William Liggett

254-5556

254-5508

Charles Johnson

254-5568

Doug Bonnar

254-5560

254-5560

254-5556

tchung

wliggett

cjohnson

dbonnar

dbonnar

Taesin Chung

254-5765

FAX Number:

254-5425

tchung

Frank Elsen

254-9829

Mary Joyce

254-9829

Mary Joyce

254-5557

Robert Lowe

254-5432

254-5320

Mark Gielecki

254-5432

254-5432

felsen

mjoyce

mjoyce

rlowe

jholihan

mgieleck

Peter Holihan

jholihan

Peter Holihan

FAX Number:

586-1076

Bob King

586-4787

Roy Kass

Roy Kass

Bob King

Dave Morehouse

586-4790

jholihan

John Herbert

Norm Crabtree
586-4790

586-4787

586-4853

$586-4360$

586-6180 rking

nkass

nkass

rking

dmorehou

jherbert

ncrabtre

(continued on next page) 
All telephone numbers are in area code 202, except where noted otherwise.

Each FAX number applies to all names that follow.

Each Internet name is followed with @eia.doe.gov

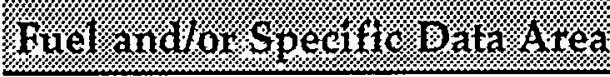

Natural Gas (cont'd):

Liquefied Natural Gas Storage

Natural Gas Liquids

Natural Gas Vehicles

Pipeline Capacity

Pricing Analysis

Production

Productive Capacity

Regulatory Issues

Reserves

Resources

Rigs Count

Spot Market

Supply Analysis

Underground Storage

Wellhead Prices

PETROLEUM: Markets

Crude Oil/Wellhead Value

Domestic Crude Oil First Purchase Report

Domestic Crude Oil Markets

Domestic Products/Prices

Fuel Oil Sales

Petroleum Demand Analysis

Petroleum Futures Market Analysis

Petroleum Inventory Analysis

Refineries/Acquisition Cost

\section{PETROLEUM: Supply}

Crude Oil Production

Exports

Imports

Natural Gas Processing

Oxygenate Data

Propane Data

Refinery Operations

Stocks

Supply and Disposition

Transportation

Weekly Petroleum Status Report

OIL AND GAS: Production and Reserves Drilling and Rigs Count
Nanie

FAX Number:

James Tobin

David Hinton

Rosemary Jameson

James Tobin

Mary Carlson

Donna Guerrina

James Hicks

Joan Heinkel

John Wood

Dave Morehouse

Bob King

James Keeling

James Tobin

Rosemary Jameson

Donna Guerrina

FAX Number:

Alan Griffith

Alan Griffith

Alan Griffith

Charles Riner

Kenneth Platto

Alice Lippert

Charles Dale

Charles Dale

Alan Griffith

Elizabeth Scott

FAX Number:

David Hinton

John Nealey

Claudette Graham

David Hinton

Irv Chamberlain

David Hinton

Evie Harper

Mike Conner

Nancy Masterson

Mike Conner

Larry Alverson

FAX Number:

Bob King
Telephone rinternet.

586-1076

586-4835

586-2990

586-6229

586-4835

586-4749

586-6135

(214)767-2200/

FAX: 767-2204

586- 4680

(214)767-2200/

FAX: 767-2204

586-4853

586-4787

586-6107

$586-4835$

586-6229

586-6135

jtobin

dhinton

rjameson

jtobin

mcarlson

dguerrin

jhicks

jheinkel

jwood

dmorehou

rking

jkeeling

jtobin

rjameson

dguerrin

586-4913

586-7225

586-7225

586-7225

586-6610

586-6364

586-9600

586-1805

586-1805

586-7225

586- 1258

agriffit

agriffit

agriffit

criner

kplatto

alippert

cdale

cdale

agriffit

escott

586-5846

586-5994

586-9670

586-9649

586-2990

586-9594

586-2990

586-5786

586-1795

586-8393

586-1795

586-9664

dhinton

jnealey

cgraham

dhinton

ichamber

dhinton

eharper

mconner

nmasters

mconner

lalverso

586-1076

586-4787 bking

(continued on next page) 
All telephone numbers are in area code 202, except where noted otherwise.

Each FAX number applies to all names that follow.

Each Internet name is followed with @eia.doe.gov

Guel andor Specific eata Area Name Intephone. Intermet

OIL AND GAS: Production and Reserves (cont'd)

Production

Resources

Reserves

MULTIFUEL: Consumption

Commercial Buildings Sector Characteristics, Consumption, and Expenditures

Commercial Buildings Sector Analysis of Consumption and Conservation Trends

Integrated Historical Data

Manufacturing Sector Characteristics, Consumption and Expenditures

Manufacturing Sector Analysis of Consumption and Conservation Trends

Residential Sector Characteristics, Consumption and Expenditures

Residential Sector Analysis of Consumption and Conservation Trends

Residential Transportation Sector Characteristics, Consumption, and Expenditures

Residential Transportation Sector Analysis of Consumption and Conservation Trends

State-Level Consumption, Prices, and Expenditures

Transportation Program Development Related to Alternative Fuels

INTERNATIONAL:

International Energy Analysis; Petroleum and Contingency Analysis

International Energy Statistics; Country Production and Consumption of Major Fuels

ECONOMIC:

Corporate Finance

Energy Taxation

Foreign Investment

Investment and Expenditures in Refining, Marketing, and Transport

Oil and Gas Exploration and Development

Expenditures (Foreign and Domestic)

(continued on next page)
FAX Number:

586-1076

Yousufuddin Mir

Dave Morehouse

John Wood

(214)767-2200/ myousufu

FAX:767-2204

$586-4853$

(214)767-2200/

FAX:767-2204

dmorehou

jwood

586-0018

FAX Number:

586-1135

mjohnson

Eugene Burns

586-1125

eburns

Samuel E. Brown

586-5103

sbrown

John Preston

586-1128

jpreston

Mark Shipper

586-1136

mshipper

Wendel Thompson

586-1119

wthompso

Wendel Thompson

586-1119

wthompso

Ron Lambrecht

$586-4962$

rlambrec

Ron Lambrecht

586-4962

rlambrec

Julia F. Hutchins

586-5138

586-1132

jhutchin

Icarleto

FAX Number:

586-9753

Derriel Cato

586-6574

dcato

Louis DeMouy

586-6557

ldemouy

FAX Number:

586-9753

Jon A. Rasmussen

586-1449

Dennis W. Sumner

586-8597

Jon A. Rasmussen

586-1449

Kevin G. Lillis

586-1395

jrasmuss

dsumner

jrasmuss

Marie N. Fagan

$586-1452$

mfagan 
All telephone numbers are in area code 202, except where noted otherwise.

Each FAX number applies to all names that follow.

Each Internet name is followed with @eia.doe.gov

\begin{tabular}{|c|c|c|c|}
\hline Fúl and dor Specific Oata 4 rea & Name & \multicolumn{2}{|c|}{ Wetephone } \\
\hline FORECASTS: & FAX Number: & $586-3045$ & \\
\hline Annual Energy Outlook/Midterm Projections & Susan H. Shaw & $586-4838$ & sshaw \\
\hline $\begin{array}{l}\text { Coal Production/Minemouth Prices/Midterm } \\
\text { Projections }\end{array}$ & Michael Mellish & $586-2136$ & mmellish \\
\hline $\begin{array}{l}\text { Coal Distribution/End-Use Prices/Midterm } \\
\text { Projections }\end{array}$ & Richard Newcombe & $586-2415$ & rnewcomb \\
\hline Coal Exports/Midterm Projections & Melinda Hobbs & $586-2152$ & mhobbs \\
\hline Commercial Demand/Midterm Projections & Stephen Wade & $586-1678$ & swade \\
\hline Crude Oil Supply/Midterm Projections & James Diemer & $586-6126$ & jdiemer \\
\hline Electricity Generation and Cost/Midterm Projections & J. Alan Beamon & $586-2025$ & abeamon \\
\hline Electricity Prices/Midterm Projections & Art Holland & $586-2026$ & aholland \\
\hline Greenhouse Gases & Arthur Rypinski & $586-8425$ & arypinsk \\
\hline Industrial Demand/Midterm Projections & T. C. Honeycutt & $586-1420$ & choneycu \\
\hline International/Midterm Projections & Linda Doman & $586-1041$ & Idoman \\
\hline Macroeconomic Analysis/Midterm Projections & Ronald F. Earley & $586-1398$ & rearley \\
\hline & Kay A. Smith & $586-1455$ & ksmith \\
\hline National Energy Modeling System & Mary J. Hutzler & $586-2222$ & mhutzler \\
\hline & Susan H. Shaw & $586-4838$ & sshaw \\
\hline Natural Gas Markets/Midterm Projections & James Diemer & $586-6126$ & jdiemer \\
\hline Natural Gas Supply/Midterm Projections & James Diemer & $586-6126$ & jdiemer \\
\hline $\begin{array}{l}\text { Nuclear Energy, Domestic and International/ } \\
\text { Midterm and Long-Term Projections }\end{array}$ & Robert T. Eynon & $586-2315$ & reynon \\
\hline Petroleum Product Markets/Midterm Projections & Bruce Bawks & $586-6579$ & bbawks \\
\hline Renewable Energy/Midterm Projections & Perry Lindstrom & $586-0934$ & plindstr \\
\hline Residential Demand/Midterm Projections & Stephen Wade & $586-1678$ & swade \\
\hline $\begin{array}{l}\text { Short-Term Energy Forecasts-Supply, Demand, } \\
\text { and Prices }\end{array}$ & David W. Costello & $\begin{array}{c}586-1468 / \\
\text { FAX: } 586-9753\end{array}$ & dcostell \\
\hline Transportation Demand/Midterm Projections & David Chien & $586-3994$ & dchien \\
\hline World Oil Prices/Midterm Projections & G. Daniel Butler & $586-9503$ & gbutler \\
\hline STANDARDS AND STATISTICAL METHODS: & FAX Number: & $254-9700$ & \\
\hline Data and Modeling Quality & Doug Hale & $254-5380$ & \\
\hline EIA Metric Program & Jay Casselberry & $254-5348$ & jcasselb \\
\hline EIA Standards Program & Jay Casselberry & $254-5348$ & jcasselb \\
\hline
\end{tabular}



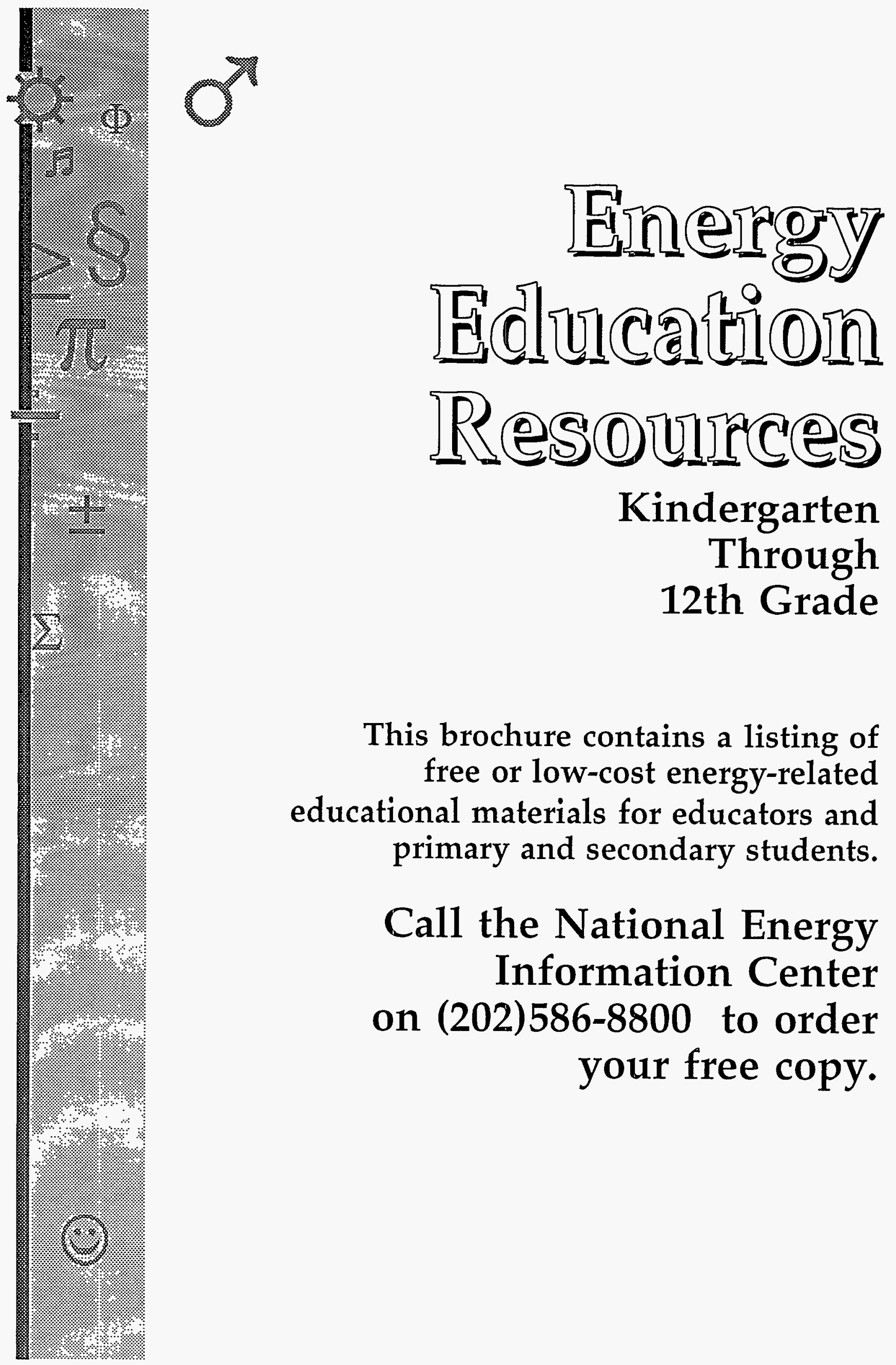

This brochure contains a listing of free or low-cost energy-related educational materials for educators and primary and secondary students.

\section{Call the National Energy Information Center on (202)586-8800 to order your free copy.}




\section{GPO Orders}

\section{Superintendent of Documents Publications and Subscriptions Order Form}

Charge your order.

It's Easy!

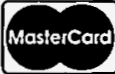

To fax your orders (202) 512-2250

Publications Please Type or Print (Form is aligned for typewriter use.)

\begin{tabular}{|c|c|c|c|c|}
\hline Qty. & Stock Number & Title & $\begin{array}{c}\text { Price } \\
\text { Each }\end{array}$ & $\begin{array}{c}\text { Total } \\
\text { Price }\end{array}$ \\
\hline & & & & \\
\hline & & & & \\
\hline & & & & \\
\hline & & & & \\
\hline & & & & \\
\hline
\end{tabular}

\section{Subscriptions}

\begin{tabular}{|c|c|c|c|c|}
\hline Qty. & (List ID) & Title & $\begin{array}{c}\text { Price } \\
\text { Each }\end{array}$ & $\begin{array}{c}\text { Total } \\
\text { Price }\end{array}$ \\
\hline & & & \\
\hline & & & & \\
\hline & & & & \\
\hline & & & & \\
\hline
\end{tabular}
NOTE: Prices include regular domestic postage and handling and are subject to change.
International customers please add 25\%.

(Company or Personal Name)

(Please type or print)

(Additional address/attention line)

(Street address)

(City, State, ZIP Code)

(Daytime phone including area code)

(Purchase Order No.)

Mail To: Superintendent of Documents

P.O. Box 371954, Pittsburgh, PA 15250-7954
For privacy protection, check the box below:

$\square$ Do not make my name available to other mailers Please choose method of payment:

$\square$ Check Payable to the Superintendent of Documents

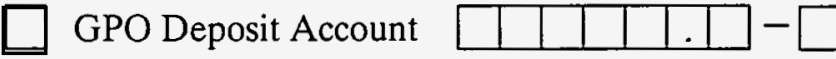

$\square$ VISA or MasterCard Account

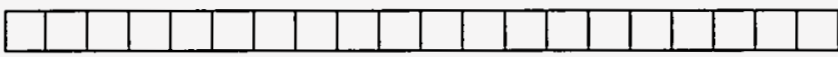

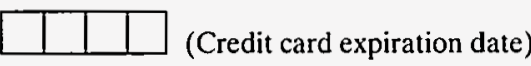

Thank you for your order!

(Authorizing Signature)

October 1995 


\section{NTIS Orders}

\section{U.S. DEPARTMENT OF COMMERCE}

TECHYOLOGY ADMINISTRATION

\section{ORDER FOAM}

\section{SHIP TO ADDRESS}

CUSTOMER MASTER NUMBER (IF KNONN)

(2)

ATENTIONINAVE

SRGANIZATION TMSPN/ROOW NUMBER

\section{STREET ADORESS}

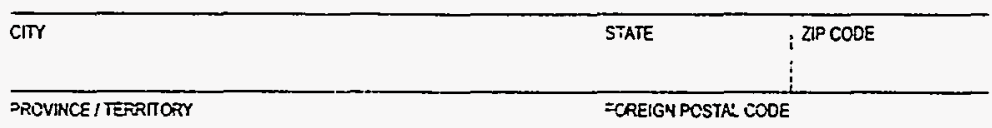

COUNTRY

\begin{tabular}{ll}
\hline PHONE NUMBER & FAX NUMBER \\
\hline CONTACT NGHE & 1 \\
\hline
\end{tabular}

\section{METHOD OF PAYMENT}

曰Check / Money Order enclosed for \$

(PAYARLE IN US DOLLARS)

$\square$ NTIS Deposit Account Number.

$\square$ VISA $\square$ MasterCard $\square$ American Express

CREDT CARO MUMBER

EXPIRATION OATE

CAROHOLDERS NAME

SIGMATURE RREOURED TO VAL IOATE ALL OPDERSI

\section{DTIC USERS OHLY}

COOE

CONTRACT NUMBER RAST SUX DGGIS)

ORDER BY PHONE (ENGATE MAR TMEI

$\vdots: 30$ a.m. - 5:00 o.m. Eastem Time. $M-F$.

Eales Desk: (703) $487-4650$

Jubscriptions: (703) 487-4630

20 (heanng umbared only): (703) $487-4639$

ORDER BY FAX

24 houts 7 days a week: (703) 321.8547

- s yenfy receid of fax: call (703) 487-4679

7.00 a.m. $-5: 00$ ग.m. Eastem Time, $M$ - F

ORDER BY MUL

Vational Technical informaton Service

\$285 Port Royal Road

Sxmgheld, VA 22161

RUSH SEAVKCE (OO NCT WAL RUSH ORDESS)

- $800-553-N T I S$

ZUSH service avalable for acditional fee.

FEDYORLD

Pease call for connect informaton: (703) 487-4608.

BUL ME

U.S. Canada. and Mexico onty.)

DO NOT USE THIS FORH.

VTS will gladly bill your oroer. for an additional tee of

57.50. A request to be billed must be on a ourchase order $x$ company letterhead. An authorizing signzare, contact

rame, and telephone number should be incured with this :equest. Requests may be mailed or laxed.

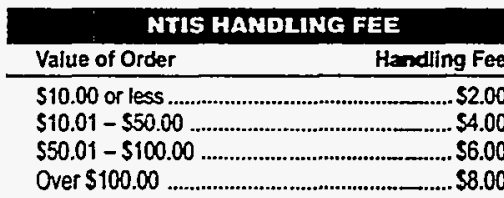

Add $\$ 2.00$ to handling fee for orders semt outside the Unied States. Canada, and Mexoco.

\section{PRODUCT SELECTION}

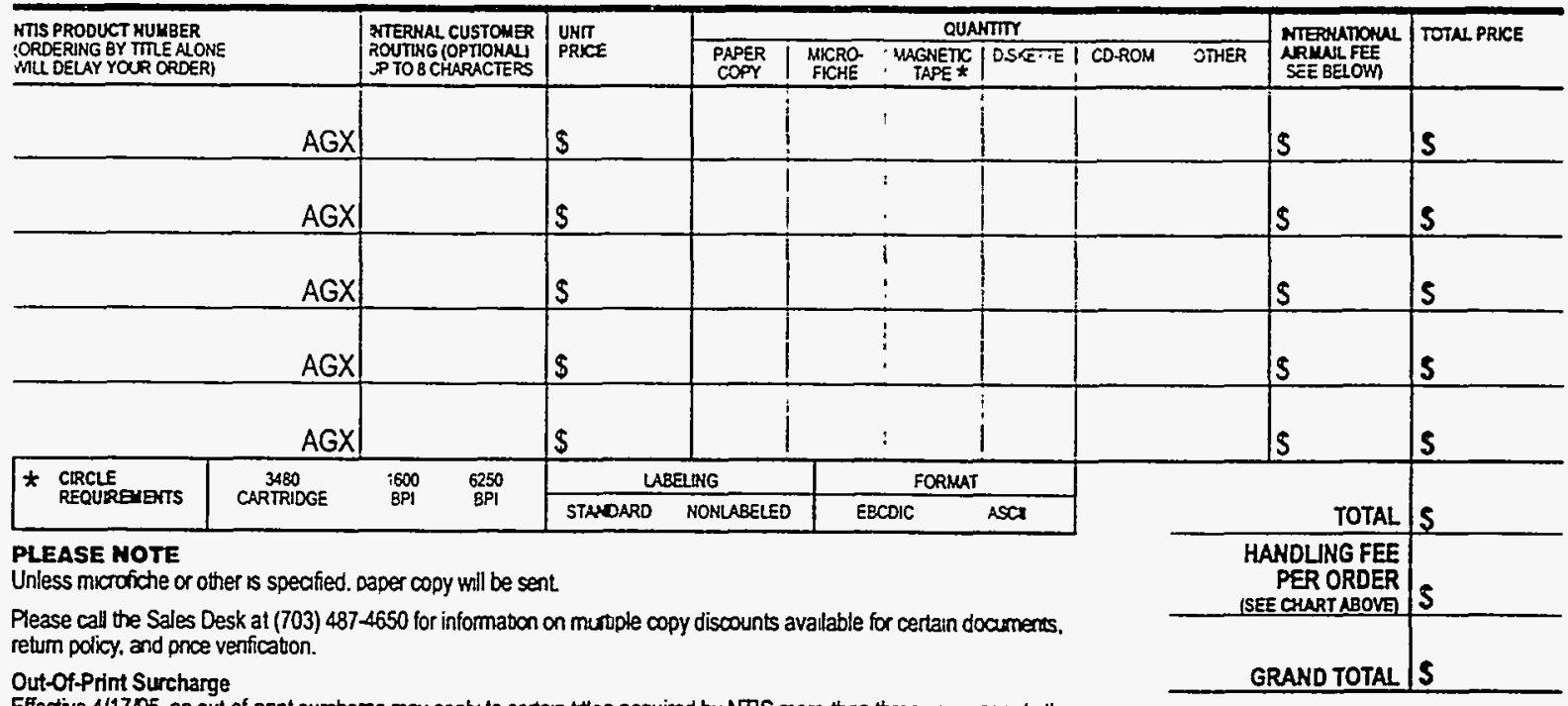

Effective 4/17/95, an out-of-prnt surcharge may apply to certain thes acquired by NTS more than three years pnor $b$ the current calencar year, please call to verniy price.

International Aimail Fees

Canada ano Mexico add $\$ 4$ per paper cooy report $\$ 1$ per m:crofiche copy. Other countnes add $\$ 8$ per paper copy resort

$\$ 1.25$ per morofiche copy. (Paper copy reports and microfiche copes are shipped surface mall unless aimat is spectied.)

Thane you for your orderl Prices are subject to change. All previous versions of this form are obsolete. 


\section{NEIC Orders}

\section{NATIONAL ENERGY INFORMATION CENTER ORDER FORM}

TO ORDER FREE PUBLICATIONS--TO NOTIFY NEIC OF CHANGE OF ADDRESS

--TO CANCEL A MAILING LIST PUBLICATION

Mail to: National Energy Information Center, El-231

Energy Information Administration

Room 1F-048, Forrestal Building

Washington, DC 20585

\section{Name}

\section{Business Affiliation}

\section{Address}

City and State

Zip Code

$\frac{(1)}{\text { Phone number with area code }}$

Mail List I.D. Number (Found in upper left corner of your mailing label.)

$\left(\frac{1}{\text { FAXNUR }}\right.$

FAX Number

$\square$ Change of address.

$\square$ Add name to mailing list for free publication(s) as listed below.

$\square$ Take name off mailing list for publication(s) as listed below.

$\square$ Send the free publication(s) as listed below. 
Energy Information Administration

U.S. Department of Energy

Forrestal Building, El-231

Washington, DC 20585

OFFICIAL BUSINESS

Address Correction Requested 